\title{
EFFECTS OF LEADERSHIP STYLE ON ORGANIZATIONAL CLIMATE AT A SELECTED GOVERNMENT AGENCY IN KOTA KINABALU, SABAH
}

\author{
Estherwene Philip ${ }^{1, *}$, Dzurizah Ibrahim ${ }^{2}$, and Kee Y. Sabariah Kee Mohd Yussof ${ }^{3}$
}

Faculty of Humanities, Arts and Heritage (Industrial Relations Programme) Universiti Malaysia Sabah, Jalan UMS, 88400 Kota Kinabalu, Sabah.

\author{
E-mail: esther_philip2004@yahoo.com \\ E-mail: idzuri@ums.edu.my \\ E-mail: keesabariah@ums.edu.my
}

\begin{abstract}
This case study adopted qualitative research using ethnography method. The study investigated the effects of leadership styles on the organizational climate at a selected government agency in Kota Kinabalu, Sabah. A total of 25 employees from six departments were interviewed to gather data for analysis of the real life experience of employees. The results would be beneficial in an organization for both the employer and employee. The different types of leadership styles, emotions, feelings, self-esteem and emotional management, employees' relationship and types of training in creating organizational climate were also discussed. The result of the study is important for policy implementation, employees' career development, theoretical knowledge and understanding the status of the organization. The study also found that leaders who failed to exhibit strong character, making the best use of resources and produce results at organization would not be able to achieve and sustain effective administration, achieve goals, sustain quality and deliver first-rate services. The study would also provide recommendations based on the findings.
\end{abstract}

\section{Keywords:}

Employment relationship, leadership, organizational climate, qualitative study. 


\section{Introduction}

The study on leadership styles and organizational climate have been popularized by Novac \& Bratanov, 2014; Deli et al., 2015; Abdulkadir, 2012 and Ferrie et al., 1990. Scholars such as Permarupan et al. (2013), Maamari and Majdani, (2017), Goleman et al. (2002); Hamidianpour et al. (2015) and Deli et al. (2015) also agreed leadership styles are positively associated with organizational climate. Bennis (2007) added that relationships between leader and employee as well as the quality of the organizational climate, are significantly influenced by the leadership style (Hackman \& Wageman, 2007).

World Bank lead public sector specialist Rajni Bajpai summarized the performance of government department together with people in the organization is lower compare to 1991 and 2014. Civil service average performance between 1991 and 2014 were higher as to compare in 2018, which indicate a decline in performance (freemalaysiatoday.com, 3 July 2019). In consonant with the remarkable statement made by World Bank Report, Novac and Bratanov (2014) also revealed that people's general perceptions on government departments responsible for putting control government plans into action seldom reach their goals. Authors added that government departments are also incompetent in utilizing the resources and unproductive employees due to dissatisfaction in leaders behaviour, payment, recognition an career prospects. Therefore, the paper is attempted to investigate the effects of leadership styles on organizational climate at a selected government agency in Kota Kinabalu, Sabah.

\section{Literature review}

According to Novac and Bratanov (2014) leadership style can make difference in the organization. Leaders' ability implementing the most appropriate leadership model will reconcile organization's values and employees and creates favourable organizational climate. Inappropriate leadership style affects organizational climate due to discontent people. Bass \& Riggio (2006) confirmed that climate and leadership styles are interdependence. However, Abdulkadir (2012) and Ojokuku et al. (2012) further specified that autocratic and bureaucratic leadership style are insignificant to organizational climate.

Hassan et al. (2016) denoted leadership styles as a process to influence others to accomplish an objective and directs the organization to be more cohesive and coherent. Dele et al. (2015) illustrated leadership styles 
provide direction, implement plans and motivate people Niculaţă (2015) illustrated leadership style as a unique, personal way of viewing the world and act based on work behaviours and situations in the organization. Fu-Jin et al. (2010) further illustrated that leadership styles which demonstrate concern, care and respect for employees increases performance and thereby effects organizational climate.

Niculaţă (2015) Leader implement work style by managing and channelling personal energy (extraversion-introversion), specific ways to gather information (sensation and perception-intuition), decision making patterns (reason based-emotional based) and life management patterns (reasoning, judgement of values and perception). Author added that the work style factors include decision making, flexibility, and involvement in ones' work, management abilities, competitiveness, creativity, information procession and interpersonal orientation.

Monika \& Kaliyamurthy (2017) pointed out organizational climate as a set of device on how organization deals with employees and other people who are related to the organization. Novac and Bratanov (2014) further illustrated organizational climate as "emotional components (experiences, fears, positive or negative feelings of the employees), cognitive (opinions, beliefs, expectations, rumours etc) and behavioural (involvement, slow pace, absences, protests etc) of a team."

Hamidianpour et al. (2015) revealed that leadership styles are the most important factors affecting the organizational climate. The more leadership styles mastered by leaders, the more power he has in shaping the organizational climate (Goleman et al., 2002). Maamari and Majdani (2017) confirmed that leadership styles effect employee's perceptions on organizational climate at various levels.

According to Permarupan et al. (2013), supportive managerial style is related to harmonious organizational climate as this type of leadership ensure employees gain benefits such as appreciation towards achievement, career development, growth and harmonious organizational climate. In addition to that supportive leadership style also offers quality and supportive working environment to gain leverage in hiring and retain valuable people. Lewin et al. (1939) added that certain leadership styles create certain social climate that affect productivity (Abdulkarim, 2013). Dele et al. (2015) further illustrated that autocratic and bureaucratic leadership style also associated with organizational climate. Ko and Kang (2019) in Lemons, Newsome and 
Brashears (2013) added leadership behaviour effects directly to organizational climate.

Hassan et al. (2016) listed leadership styles as autocratic, democratic, laissez-faire, transactional, task-oriented, interpersonal, transformational, charismatic, distributed, participative, directive, ethical, authoritative, authoritarian, intellectual, instrumental, coercive, team-oriented, delegative, autonomous, coaching, affiliative, supportive, relationship-oriented, consultative/advisory, humane-oriented, expressive, visionary, pacesetting, narcissist, E-leadership, achievement-oriented, authentic, servant, citizen, aversive, empowering, opinion and self-protective. Jackson (2009) presented four specific leadership styles such as commandos, coaches, counsellors and conductors.

Fuente and Sánchez (2015-2016) stated that there are three leadership styles developed by Lewin (1939) which known as authoritarian style, participative style and delegative style.

According to Hassan et al. (2016) a task-oriented leader has its prime focus on achieving optimal efficiency with organizational resources. Relations-oriented leadership style emphasizes on building leader-member efficiency relationship, supporting, developing, recognizing and empowering subordinates (Yukl, 2009). Relations-oriented leaders have confidence in the team's ability and provide complete support to the subordinates to complete the task at hand (Tabernero et al., 2009). Most experts agreed situational leadership approach as an effective method of management (Northouse, 2013).

Burns (1978) distinguished that transactional leaders motivate their followers by appealing to their self-interest, whereas transformational "leaders and followers raise one another to higher levels of morality and motivations " (Burns, 1978, p.20). Bass (1985) described transactional leadership as an exchange of reward for compliances, whereas the transformational leader lets followers feel admiration, trust and loyalty, and are thus motivated to do more than what is expected from them (Vrba, 2007).

The transformational leadership style is based more on emotional than transactional leadership (Palmer et al., 2001). Most organizations prefer transformational leader ship style as it leads to higher employee satisfaction, trust and commitment (Vrba, 2007; Cavazotte et al., 2012). Many scholars discuss that transformational leadership promotes better and greater 
organizational performance (Lowe et al., 1996; Harms, 2010; Foster and Roche, 2014).

Blanchard et al. (1985) revealed that directive style is appropriate when the followers are not competent, committed, insecure or unwilling to perform a task. The leader focus highly on the task by making all the decisions and not much in the relationship. The coaching style suits well with competent, committed and motivated followers. Coaching style suits well when the followers are quite competent and committed, and motivated to carry out the tasks they are given. Leader who adopt this style ask opinion of other followers while still keeping the power to make decisions and directing the group. Although he does not give up his power, it is an improvement if we compare it with the directive style because it opens a communication channel that runs both way as the leader takes into account how his followers feel about the decisions he makes, his suggestions and opinions. Supportive leadership style works when the followers are competent and quite committed, but not motivated or insecure about the task. Supportive leadership highly focused on the relationship and not much on the task. Supportive-oriented styles of leadership are more participative, receptive and consultative to subordinates, as well as friendly work atmosphere (Kassim \& Sulaiman, 2011). Delegative style is the right way to lead a team when the followers are competent and committed, motivated and willing to do job. The leader focuses neither on the task nor the relationships. This leadership style requires a high level of trust as the leader is no longer in control of their tasks or the decisions the group makes. Leaders' approach based on followers maturity. Delegative leader succeeds when he correctly identifies his followers maturity stage and adapts his leadership style to it, focusing more on the task to be performed and relationships among the group (Blanchard and Hersey, 1969; Blanchard et al. 1985).

Fuente and Sánchez (2015-2016) stated that participative or democratic styles include the entire team in decision making process. This type of leadership realized he is not always right and he may not have all the information needed to make the best decision, so subordinate feedback is welcome to fill up the missing knowledge and skills. That way the final decision will be better for the whole group's sake (Lewin, 1939).

Lewin (1939) added that participative leaders do not give away all their power, but do not use it in a dictatorial way either. Followers leaded in participative style feel that they are treated fairly and this increases their motivation, creativity, commitment to the group. In participative style, leader 
and follower relationship is closer than in the authoritarian or the delegative. Participative leadership styles increases motivation, fosters creativity and takes into account all points of views. Collaboration and cooperative environment lead to leader employees close relationship. However, this style is not suitable for inexperienced team.

\section{Method and study area}

Qualitative research method is being adopted in this study. According to Berg (2001) qualitative research is capable in assessing un-calculable facts through observations and interviews that portrays people through their personal traces such as symbol representing a speech sound or a written message, pictures and printed publication. Rubin \& Rubin (1997) illustrated qualitative interviews may appear similar to ordinary discussion, but are dissimilar in terms of how sharp the researcher hear with thoughtful attention in picking up on key words, phrases and thought. Berg (2001) illustrated ethnography involves the most in-depth interviews, observational and data collection in the ground. Through ethnography researchers are able to examine various phenomena as perceived by participants and represent these observations. The sampling of the study consists of 25 civil servants from 6 departments at a selected government agency in Kota Kinabalu, Sabah. Pseudonyms are used for confidentiality reason. The data is analysed using iterative process in which cultural ideas that arise during active involvement in the field are transformed, translated or represented in a written document. It involves data sifting and sorting to detect and interpret thematic categorizations, inconsistencies and contradictions to generate conclusions about what is happening and why (Thorne, 2000).

\section{Results and discussion}

The findings indicate that the selected government agency adopted autocratic, bureaucratic, destructive and toxic leadership styles. Although minority of the leadership adopt democratic and laissez faire styles, the top management over ruled the organization with autocratic, bureaucratic, destructive and toxic leadership styles.

\section{a. Autocratic leadership style}

Based on employees' perceptions the organization is highly lead by an autocratic leadership. Fuente and Sánchez (2015-2016) described autocratic style as one of the most extended leadership styles adopted by aged top 
leaders and organization. It is a style based on power and obedience which depend deeply on the leader to make decision.

According to the study of Hassan et al. (2016) autocratic leadership style instruct, put very little concern for others and high distance from employees. Leaders' decision making is unilateral. Employees are incapable of performing tasks themselves and are moderately motivated. There is no career development for employees as they are instructed to follow instructions. According to Ajokuku et al. (2012) and Bennis (2007), autocratic leaders retain decision-making rights and force employees to execute strategies and services in a very narrow way that will damage the organization irreparably in the long run. Omalayo (2007) added that workers under autocratic leadership do not experience high sense of community as to compare workers under democratic style. Duanzu Wang et al. (2009) further illustrated that knowledge sharing and team communication completely mediated negative relationship between authoritarian leadership and team innovation.

As stated by Raju, a senior officer, the administration leader checks every word in his work and keep on commenting until due date of task. Leader refused to inform her expectation in order to improve the quality of the assignment. Due to time-pressure her leader ended doing the job on her own as she does not trust anyone else except her few circles of colleagues. Instead of showing employees what to do and help them to understand, she refused to speak and grow with the team. "Our leader micromanaged us for immediate team performance but without any support. She made decision on her own without consulting us. The leader neglects us! We are discouraged to express ourselves. We are at fear of this type of leadership styles, therefore opt to be silent. Too much time and money spend on brainstorming and meetings and yet there is no outcome .... Leader mandate workplace policies and procedures, to be in control. She scrutinized followers' movement by building CCTV all over the office."

As stated by Lina and Mika, secretaries to the directors, their bosses instructed them to do non office job for their personal gain.

Employees are not happy as when the leader instruct them to do their personal thing. They feel it is out of their job scope and it is not fair for them to do extra job.

As stated by Daud, a senior officer and Wan, a clerk from technology transfer complained that their leader instructed them to do job and claimed it is his effort. "Leader expect superb feedback from us and yet never compliment us." 
Employees feel cheated when assignment thrown to them and yet only the bosses get the good name. Employees wants recognition, reward and career development.

\section{b. Bureaucratic leadership style}

According to Ebrahim (2018), bureaucratic leadership style expects people working under them to follow their policies and procedures designed by them. Bureaucratic leaders are strongly committed to processes and procedures but not their people. Germano (2010) stated that the only focus of bureaucratic leaders are to complete their task in systematic manner. Sougui et al. (2015) agree this method is beneficial when the task is to be done in longer time following mentioned procedure.

The followings have been retrieved from respondents during the interview section.

Mika, an officer stated that: "We are slave of the processes and procedures. Most of the processes and procedures are redundant and no longer usable to the organization however we are forced to follow the rules and procedures." The processes and procedures are being created to ensure that the leader is in control to execute their power.

Jojo a senior officer, Musa a support staff and Hong, a driver complained that their leaders are very strict and particular on the rules. Too much on the written rules that there is no short cut doing the job. Over-ride by the rules, job is always delay with her. Leader is so pathetic on position and grades. Leader sabotage work to show that only her department is working and not the other department.

The organization have been operating for 30 years and it will only make sense that rules and procedures need amendment. Without amendment not only the employees but also the organization will not be able to move forward.

Frank a driver, Lucia a support staff, Kitty and Kuchi both senior officers stated that they are suffocated with the style of leader in the organization. Leader check on us every single time...She check on our grooming, observe followers doing their task. She treated us like a little kid by instructing every single step in our task. We have been in the organization for many years and we don't need a leader who wants to know everything. She is so rigid!"

Employees are tired with the situation and feel demotivated as leaders are demanding, scrutinizing and do not trust them. Employees feel that 
leaders should concentrate on organization development rather that looking for employees' mistakes.

\section{c. Destructive Leadership Style}

According to Einarsen et al. (2007) destructive leadership style is a "systematic and repeated behaviour by a leader, supervisor or manager that violates the legitimate interest of the organization by undermining and/or sabotaging the organization's goals, tasks, resources and effectiveness and/or the motivation, well-being or job satisfaction of his/ her subordinate". Erickson et al. (2015) added destructive leader behaviour may harm or intends to harm organizations or followers. Einarsen et al. (2007) further described destructive leadership style as tyrannical, deflected and complimentary- untrustworthy leadership behaviour. Tyrannical demeanor ruin subordinate's interest, contentment or job comfort without imperatively running organization's goals. Derailed leadership exhibit anti-subordinate attitude such as imperious, degradation, controlling, betrayal or provocation and anti-achievement behaviour such as skipping, cheating, and misrepresentation or looting. Authors added that derailed leadership unable to accustomed current positions or established important management competence and heartless to subordinates. Derailed leadership blustering and aggressive style of management annoyed subordinate (McCall \& Lombardo, 1983).

Shaw, Erickson \& Harvey (2011) also have conceptualized and analyzed destructive leadership using seven flock of behaviors that ranged from micro-managing to over governing that lead to agony and discouragement for employees.

Einarsen et al. (2007) illustrated that tyrannical leader used oppressive and extreme methods in obtaining results. Tyrannical leaders generate income by threatening, degrading, criticizing and wield subordinates to complete assignments. Tyrannical leadership behavior is similar to Blake and Mouton (1965) leadership style known as 'AuthorityObedience' where leader focus on assignment attainment, limiting communication and less concern to their subordinates. Somber relationship in the organization deprived subordinates motivation, well-being and job satisfaction that may lead to bullying, harassment, incivility and mistreatment. Mawritz, Dust \& Resick (2018) further illustrated that hostile climate looms in the organization when employees are suspicious, distrustful and combative toward others. 
Finding as following indicate the existence of destructive leadership at the selected government agency.

Anel an officer, Tasha and Prima both senior officers stated that leaders make decisions that benefit them. Followers input are not encouraged and leader attacks anyone that disagrees with them. Leader is arrogant and self serving...Leader stay away from followers which leads them to gossip and speculate. We no longer trust anyone in the office.

Ahmad a senior officer, Adam and Carol both officers and Cheah a secretary, stated that their leader superior's instruction despite of knowing that the instruction is destructive to the organization .

Lario and Eve both support staff, Firdaus an officer, Sakhtivel a senior officer and Lucia, a clerk, stated that they do not get enough guidance and are not sure of their role and what top leader's expectation. Top leader refuse to speak, refuse to smile as if we don't belong to the organization.

The head of the organization must have forgotten that the organization is a government agency and does not belong to them. The team which consists of top management, officers and support staff are recruited officially to serve carry out the government roles. It is a waste of money if they are not trusted to do their job.

\section{Conclusion}

Leadership styles in the selected government agency definitely have affected the organizational climate. Autocratic, bureaucratic and destructive leadership styles demotivated employees and this type of leadership style is no longer popular among civil servants. These types of leadership destroyed trust between leader-employees. Lack of trust, focusing too many rules and procedures as a point of control have put a distance to leader employee relationship, which has formed to a disunited climate in the organization. Leadership styles mostly for personal gain generate a very low morale, sincerity, commitment, understanding and creativity. Unless there is interference from Civil Service Department to come up with an organization behaviour training, it is a fear that the performance of civil servants in Malaysia continue dropping due to the unsuitable style of leadership which affects the organizational climate. Wrong leadership styles would drag apart government agencies in Malaysia.

\section{Acknowledgement}


We would like to thank all those who have stimulating suggestions and encouragement to coordinate in writing this paper. A special gratitude to :

Dr. Badariah Ab Rahman for the useful comments and remarks, Dr. Maureen De Silva for opening my door to the journey, all participant who willingly shared their time and experience during the interview and also to my loved ones who have supported me throughout keeping my soul in harmony and assisted me putting pieces together.

\section{References}

Abdulkadir, D.S. (2012). "Strategic human resource management and organizational performance in the Nigerian insurance industry: the impact of organizational climate." Business Intelligence Journal, 5(1), 8-20.

Bass, Bernard M; \& Riggio, Ronald (2006). Transformational Leadership, $2^{\text {nd }}$ Edition.

Berg, Bruce Lawrence (2001). Qualitative research methods for the social sciences. $4^{\text {th }}$ edition. California State University, Long Beach.

Bhat, Adi. Qualitative Research: Definition, Types, Methods and Examples. https://www.questionpro.com/blog/qualitative-research-methods/

Brink, Beatrix (2019). Coping with destructive leadership behaviour: A qualitative study of non-physical abuse in South African companies.

Dissertation. Stellenbosch University https://scholar.sun.ac.za

Cavazotte, Flavia; Moreno, Valter; \& Hickmann (2012). Effects of leader intelligence, personality and emotional intelligence on transformational leadership and managerial performance. The Leadership Quarterly, 23(3),443-455.

Dele, Awolusi Olawumi; Nanle, Magaji; \& Abimbola, Odunlami Samuel (2015). Impact of Leadership Style on Organizational Climate in the Nigerian Insurance Industry. International Journal of Business and Industrial Marketing,1(3),45-52.

Duanxu, Wang; Hujuan, Xue; \& Jie, Xu (2009). The Mechanism of Leadership Styles Affecting Team Innovation in the PRC, IEEE.

Ebrahim, Hasan Al Khajeh (2018). Impact of Leadership Styles on Organizational Performance. Journal of Human Resources Management Research.

Einarsen, S.; Aasland, Merethe Schanke; \& Skogsad, Anders (2007). Destructive leadership behaviour: A definition and conceptual model. The Leadership Quarterly (11). doi:10.1016/j.leaqua.2007.03.002 
Erickson, Anthony; Shaw, Ben; Murray, Jane; \& Branch, Sara (2015). Destructive Leadership: Causes, consequences and countermeasures. Organizational Dynamics.

Fiedler, Fred E; Chemers, Martin M; \& Mahar, Linda (1978). The Leader Match Concept. Administrative Sciences Quarterly, 23(3), 496-505.

Foster, C; \& Roche, F. (2014). Integrating trait and ability EI in predicting transformational leadership. Leadership and Organizational Development Journal, 35(4), 316-334.

Fuente, Sergi Bartina de la (2015-2016). The Effects of Leadership and Internal Communication on Organizational Climate, Universitat Jaume, 1-50.

Fu-Jin, W.; Shieh, C. \& Tang, M (2011). Effect of leadership style on organizational performance as viewed from human resources management strategy. African Journal of Business Management, 4(18), 3924-3936.

Germano, M.A. (2010). Leadership Style and Organization Impact. Online at http://www.ala-apa.org

Goleman, D.; Boyatzis, R.E. and McKee, A (2002). The New Leaders: Transforming the Art of Leadership into the Science of Results, Little Brown, London.

Hackman, J.R, \& Wageman, R. (2007). Asking the right questions about leadership: Discussion and conclusions. American Psychologist, 62 (1), 43-47.

Hamidianpour, F.; Esmaeilpour, M.; \& Dorgoe, A (2015). The influence of emotional intelligence and organizational climate on creativity and entrepreneurial of small to medium-sized enterprises. European Online Journal of Natural and Social Sciences, 1, 20-30.

Harms, P.D.; Credè, Marcus (2010). Emotional Intelligence and Transformative and Transactional Leadership: A Meta-Analysis. Journal of Leadership \& Organizational Studies, 17(1), 5-17.

Hassan, Hamid; Asad, Sarosh; \& Hoshino, Yasuo (2016). Determinants of Leadership Style in Big Five Personality Dimensions. Universal Journal of Management ,4(4),161-179.

Hersey, P.; \& Blanchard, K.H. (1969). Life cycle theory of leadership. Training and Development Journal, 23(5), 26-34.

Kassim, Zorah Abu; \& Sulaiman, Mohamed (2011). Market Orientation ad Leadership Styles of Managers in Malaysia. International Journal of Leadership Studies, 6 (2).

Khajeh, Ibrahim Hasan El (2018). Impact of Leadership Styles on Organizational Performance. Journal of Human Resources 
Management Research, 2018 (1-10). Article ID 687849, DOI: 10.5171/2018.687849.

Khan, Zakeer Ahmed; Nawaz, Dr. Allah; Khan, Irfanullah (2016). Leadership Theories and Styles: A Literature Review. Journal of Resources and Management, 16.

Ko W-H; \& Kang H-Y (2019). Effect of leadership style and organizational climate on employees' food safety and hygiene behaviours in the institutional food service of schools. Food Sci Nutr,7,2131-2143.

Koy, Daniel J. \& DeCotiis, Thomas A. (1991). Inductive Measures of Psychological Climate, Human Relations, 44(3):265-285.

Kua, Kia Song (2019). Civil service decline: Between evidence and perception. Retrieved from http://www.freemalaysiatoday.com.

Kum, Franklin Dang; Cowden, Richard; \& Karodiam Anis Mahomed (2014). The Impact of Training and Development on Employee Performance: A Case Study of Escon Consulting. Singaporean Journal of Business Economics and Management Studies, 3:3: (1-34).

Legas, Addisu (15 Jun). Qualities of Effective Leadership and Its impact on Good Governance. Blog at Abyssinialaw.

Retrieved from https://www.abyssinialaw.com/blog-posts/item/1473qualities-of-effective-leadership-and-its-impact-on-good-governance

Lewin, K.; Lippitt, R., \& White, R,K. (1939). Patterns of aggressive behaviour in experimentally created "social climates." Journal of Social Psychology, 10, 271-299.

Liliana, Pedraja-Rejas; \& Emilio, Rodriguez-Ponce; \& Juan, RodriguezPonce (2006). Leadership styles and effectiveness: a study of small firms in Chile, Interciencia,31(7),500-504.

Litwin. G.H. \& Stringer, R.A. Jr. (1968). Motivation and organizational climate. Division of Research, Harvard Business School, Boston.

Lowe, K.B; Kroeck, K.G.; \& Sivasubramaniam, N. (1996). "Effectiveness correlates of transformational and transactional leadership: a metaanalytic review of the MLQ literature." The Leadership Quarterly, 7(3), 385-425.

Maamari, Bassem E.; \& Majdani, Joelle F. (2017). Emotional intelligence, leadership style and organizational climate. International Journal of Organizational Analysis,_25(2),327-345.

Micheal, A (2010). Leadership style and organizational impact. Retrieved from http://www.ala-apa.org

Monika, M.; Kaliyamurthy, K (2017). Effects of Organizational Climate in Job Satisfaction among the employees. Asian Journal of Research in Social Sciences and Humanities, 7, 217-227. 
Nahavandi, A (2002). The art and science of leadership (3 $3^{\text {rd }}$ ed.). Upper Saddle river, NJ, Prentice Hall.

Nanjundeswaraswamy, T.S.; \& Swamy, D.R (2014). Leadership styles. Advances in Management, 7(2).

Nawaz, Allah; Khan, Zakeer; \& Khan, Irfanullah (2016). Leadership Theories and Styles: A Literature Review. Journal of Resources Development and Management, 16.

Neal, A.; Griffin, M.A.; \& Hart, P.M. (2000). The impact of organizational climate on safety climate and individual behaviour. Safety Science, 34 (1-3), 99-109.

Northouse, O.G. (2013). Leadership Theory and practice, San Francisco: Sage Publications.

Novac, Carmen; \& Bratanov, Crina Iulia (2014). The Impact of the Leadership Style on the Organizational Climate in a Public Entity. Management Dynamics in the Knowledge Economy, 2 (1), 155-179.

Ojokuku, R,M.; Odetayo, T.A; \& Sajuyigbe, A.S (2012). Impact of Leadership Style on Organizational Performance: A Case study of Nigerian Banks. American Journal of Business and Management, 1(4), 202-207.

Omalayo, Bunmi (2007). Effects of Leadership Styles on Job Related Tension of Psychological Sense of Community in Work Organizations: A Case Study of Four Organizations in Lagos State, Nigeria. Bangladesh e-Journal of Sociology, 4 (2).

Palmer, B.; Walls, M.; Burgees, Z.; \& Stough, C. (2011).Emotional intelligence and effective leadership." Leadership and Organizational Development Journal, 22(1), 5-10.

Rubin, J. (1997). Qualitative Interviewing : The Art of Hearing Data (2 ed). Thousand Oaks, CA: Sage

Sharma, P.N. (2017). Moving beyond the employee: The role of the organizational context in leader workplace aggression. The Leadership Quarterly, 12:002(1-3). https://doi.org/10.1016/j.leaqua.2017.12.002

Shaw, James B; Erickson, Anthony; \& Harvey, Micheal, G (2011). A method of measuring destructive leadership and identifying types of destructive leaders in organizations. The Leadership Quarterly, 22 (4): $575-590$.

Soong, Kua Kia. (2019). Civil service decline between evidence and perceptions. Retrieved from https://www.freemalaysiatoday.com/category/opinion/2019/07/03/civ il-service-decline-between-evidence-and-perception/ 
Sougui, A.O.; Bon, A.T.B; \& Hassan, H.M.H (2015). The Impact of Leadership Style on Employees' Performance in Telecom Engineering Companies. International Conference on Tourism and Hospitality.

Tabernero, Carmen; Chambel, M. Jose; Curral, Luis; \& Arana, Jose, M (2009). The role of task-oriented versus relationship-oriented leadership on normative contract and group performance. Social Behaviour \& Personality: An International Journal, 37(10), 13911404.

Thorne, Sally (2000). Data analysis in qualitative research. EBN notebook, 70 (3).

Van Vugt, M.; Jepson, S.F.; Hart, C.M.; \& De Cremer, D (2004). Autocratic leadership in social dilemmas: A threat to group stability. Journal of Experimental Social Psychology, 40, 1-13.

Vrba, M. (2007). "Emotional intelligence skills and leadership behaviour in a sample of South African first-line managers." Management Dynamics: Journal of the Southern African Institute of Management Scientists, 16 (2), 25-35.

Yukl, G. (2009). Leadership in Organizations. New Delhi: Dorling . Kindersley 